\title{
Analisis Pengaruh Faktor-Faktor Fundamental Terhadap Harga Saham (Studi Empiris Pada Perusahaan Manufaktur Yang Terdaftar di Bursa Efek Indonesia Periode 2012 - 2015)
}

\author{
Ivan \\ Program Studi Maksi Fakultas Ekonomi \\ Universitas Tarumanagara, Jakarta \\ Niemi.niemi@hotmail.com
}

\begin{abstract}
:
Di dalam teori pasar efisien disebutkan bahwa perubahan harga suatu sekuritas saham di waktu yang lalu tidak dapat digunakan untuk memperkirakan perubahan harga dan pada teori signal disebutkan juga bahwa investor melihat tanda tanda yang dibuat oleh manajer perusahaan untuk memprediksi prospek perusahaan ke depan. Karenanya dibuatlah penelitian untuk mendapatkan bukti empiris dengan menganalisis apakah faktor faktor fundamental berpengaruh signifikan terhdap harga saham pada perusahaan manufaktur baik secra parsial maupun simultan pada perusahaan manufaktur yang terdaftar di BEI tahun 2012-2015. Faktor fundamental di sini dibagi menjadi profitabilitas, solvabilitas dan likuiditas diwakili oleh rasio ROA, ROE, NPM, DER, CashTA, TATO, dan EPS. Penelitian menggunakan Regresi Data Panel yang dibantu dengan program Eviews. Hasil penelitian secara parsial hanya variabel NPM, CashTA dan EPS yang berpengaruh signifikan sedangkan untuk variabel ROA, ROE, DER dan TATO tidak berpengaruh signifikan. Secara simultan seluruh seluruh variable secara bersama sama memiliki pengaruh yang signifikan terhadap harga saham.
\end{abstract}

In efficient market theory it is mentioned that a price change of a stock's securities in the past can not be used to estimate price changes and the theory of signals is also mentioned that investors see signs made by managers of firms to predict future outlook. Therefore, the research was made to obtain empirical evidence by analyzing whether the fundamental factor has significant effect on stock price in manufacturing companies either partially or simultaneously on manufacturing companies listed on BEI in 20122015. The fundamental factors here are divided into profitability, solvency and liquidity are represented by ROA, ROE, NPM, DER, CashTA, TATO, and EPS ratios. Research using Data Panel Regression assisted with Eviews program. The results of research partially only NPM, CashTA and EPS variables that have a significant effect while for the variable ROA, ROE, DER and TATO no significant effect. Simultaneously all the variables together have a significant influence on stock prices.

Key word : Return On Asset, Return On Equity, Net Profit Margin, Debt to Equity Ratio, Cash to Total Assets, Total Asset Turn Over, Earning per Share, Stock Price, Fundamental analysis

Kontributor : Jan Hoesad

\section{Latar Belakang}

Setiap perusahaan yang listing di Bursa Efek Indonesia atau go public sudah pasti menerbitkan sahamnya melalui pasar perdana. Kemudian lembar lembar saham ini pasti diperjualbelikan di pasar sekunder. Maka bagi investor yang memiliki lembar saham ingin harga sahamnya selalu tinggi dan tidak pernah turun. Maka dari itu investor harus bisa menganalisis harga saham tersebut karena jika salah dalam menganalisis harga saham, maka investor akan mengalami kerugian yang jumlahnya tidak sedikit.

Analisis fundamental dan analisis teknikal merupakan dua analisis keuangan yang biasa digunakan untuk menentukan harga saham. Menurut Darmadji dan Fakhruddin (2011: 149) Analisis fundamental merupakan salah satu cara untuk melakukan penilaian saham dengan mempelajari atau mengamati berbagai indikator yang terkait dengan kondisi makro ekonomi dan kondisi industri suatu perusahaan hingga berbagai indikator keuangan dan manajemen perusahaan.

Analisis fundamental adalah analisis yang berbasis pada berbagai data riil yang digunakan untuk mengevaluasi atau memproyeksi nilai suatu saham. Rasio keuangan dan rasio pasar adalah rasio rasio yang sering digunakan untuk memprediksi harga saham atau tingkat pengembalian dari suatu saham. Rasio keuangan yang biasanya berfungsi untuk memprediksi harga saham antara lain : return on assets (ROA), debt to equity ratio (DER), dan book value per share (BPS). Rasio pasar yang sering digunakan untuk menilai harga saham atau tingkat pengembalian saham adalah price to book value (PBV).

Metode lainnya yang digunakan adalah analisis teknikal. Metode ini merupakan salah satu metode yang digunakan untuk penilaian saham, di mana dengan metode ini para analis melakukan evaluasi saham 
berbasis pada data statistik yang dihasilkan dari aktivitas perdagangan yang telah lalu. Analisis teknikal mencoba melihat arah pergerakan harga saham ke depan dengan berbagai grafik serta pola-pola grafik yang terbentuk. Faktor teknikal ini diukur dengan beberapa indikator diantaranya inflasi, nilai tukar mata uang, dan risiko pasar.

Dalam hal menilai saham, analisis fundamental bertujuan untuk memastikan bahwa saham saham yang dibeli merupakan saham perusahaan yang kinerjanya baik. Di mana perusahaan memiliki ekspektasi positif terhadap pertumbuhan harga sahamnya. Analisis fundamental meminimalkan risiko membeli saham yang berkemungkinan de-listing dari papan bursa.

Oleh karena begitu banyak faktor yang dapat mempengaruhi harga saham, maka penelitian ini dibatasi hanya pada pengaruh faktor fundamental dengan melihat kondisi spesifik perusahaan : kinerja perusahaan (laporan keuangan) dengan menggunakan rasio keuangan yaitu : Return on Assets (ROA), Return on Equity (ROE), Net Profit Margin (NPM), Debt to Equity Ratio (DER), Cash to Total Assets (CashTA), Total Assets Turn Over (TATO), Earning Per Share (EPS). Ketujuh variabel tersebut dipilih karena mewakili rasio profitabilitas, rasio likuiditas dan rasio solvabilitas, dan pernah digunakan dalam penelitian terdahulu sebagai variabel penelitian serta memberikan kesimpulan yang tidak konsisten. Rasiorasio ini relevan dengan penelitian ini karena rasio profitabilitas mencerminkan tingkat keuntungan yang diberikan oleh perusahaan dan untuk rasio solvabilitas ini menunjukkan besaran aktiva yang dimiliki perusahaan yang diperoleh melalui hutang serta rasio likuiditas yang menggambarkan kemampuan perusahaan dalam melunasi hutang hutang jangka pendek perusahaan.

Hal ini sejalan karena rasio rasio profitabilitas, solvabilitas dan likuiditas menggambarkan kemampuan perusahaan dalam mengolah perusahaan untuk lebih efisien dalam menghasilkan laba serta menjaga perusahaan dalam melakukan pelunasan kewajiban kewajibannya. Hal ini akan berpengaruh terhadap keputusan investor untuk melakukan investasi atau pembelian saham pada perusahaan bersangkutan.

Menurut penelitian baresa, Bogdan dan ivanovic, "Fundamental analysis is considered to be one of the easiest ways of companies valuation. The main aim of fundamental analysis is to reveal the actual current value of the company. One of the main aims of fundamental analysis is prediction of future profits, dividends and the risk in order to calculate the true value of the stocks" namun menurut Jekaterina dan Deimant, "So, having all arguments against fundamental analysis which were presented in this paper, the question about usefulness of this tool necessarily arise in mind.". Hal ini membuat penulis mencoba menguji sejauh apa rasio keuangan dalam analisis fundamental ini memiliki efek terhadap harga saham.

Menurut beberapa hasil penelitian terdahulu menunjukkan perbedaan hasil. Penelitian Deitiana (2011) pada perusahaan yang terdaftar di LQ45 selama tahun 2004 sampai 2008 menunjukkan hanya profitabilitas yang diukur menggunakan ROE saja yang memliki pengaruh yang signifikan terhadap harga saham sedangkan likuiditas, pertumbuhan penjualan dan kebijakan dividen tidak memiliki pengaruh yang signifikan terhadap harga saham.

Menurut penelitian Pandansari (2012) yang melakukan pengujian terhadap perusahaan manufaktur yang terdaftar di BEI selama tahun 2008 sampai 2010 menunjukkan bahwa ROA, DER dan BVS secara simultan dan parsial berpengaruh positif terhadap harga saham. Sedangkan Menurut penelitian Nainggolan (2008) yang melakukan pengujian terhadap perusahaan manufaktur yang terdaftar di BEI selama tahun 2004 sampai 2006 menunjukkan hasil yang berbeda di mana secara simultan ROA, DER, ROE dan BVS tidak memiliki pengaruh terhadap harga saham. Bahkan secara parsial hanya BVS saja yang memiliki pengaruh yang signifikan terhadap harga saham sedangkan ROA, DER dan ROE secara persial tidak memiliki pengaruh yang signifikan terhadap harga saham.

Menurut penelitian Jiwandono (2014) yang melakukan pengujian terhadap perusahaan perbankan yang terdaftar di dalam indeks kompas 100 selama periode 2008 sampai 2012 menunjukkan hasil berupa EPS dan ROA memiliki pengaruh yang signifikan terhadap harga saham sedangkan ROE, ROI, AG dan CAR tidak memiliki pengaruh yang signifikan terhadap harga saham.

Menurut Seetharaman dan Raj (2011), penelitian mereka terhadap 19 bank publik berhad menunjukkan hasil bahwa EPS berpengaruh positif dan kuat terhadap harga saham berbeda dengan penelitian Gunarianto (2012) yang telah melakukan pengujian terhadap perusahaan perbankan yang listed di 
BEI selama periode 2006 sampai 2010 menunjukkan bahwa EPS, ROE dan tingkat suku bunga deposito tidak memiliki pengaruh terhadap harga saham.

Menurut penelitian Raharjo dan Muid (2013) yang melakukan pengujian terhadap perusahaan non keuangan yang terdaftar di index LQ45 selama periode 2007 sampai 2011 menunjukkan bahwa secara simultan ROE, ROA, DER, CR, EPS dan BVS memiliki pengaruh yang positif dan signifikan terhadap harga saham. Namun hanya CR saja yang memiliki pengaruh yang positif dan signifikan terhadap harga saham sedangkan ROE, ROA, DER, EPS dan BVS tidak memiliki pengaruh yang signifikan terhadap harga saham.

Menurut penelitian Pasaribu (2008) yang menguji pada beberapa sektor yang terdaftar di BEI menunjukkan bahwa secara simultan seluruh rasio yang diuji berpengaruh signifikan terhadap harga namun secara parsial rasio pertumbuhan perusahaan, rasio profitabilitas, rasio leverage, rasio likuiditas, dan rasio earning per share saja yang memiliki pengaruh yang signifikan terhadap perusahaan sedangkan rasio turn over dan price earning ratio tidak memiliki pengaruh yang signifikan terhadap harga saham. Untuk rasio CashTA memiliki pengaruh yang signifikan di industri properti dan real estate.

Menurut penelitian Tampubolon dan Doloksaribu (2011) yang melakukan pengujian terhadap seluruh emiten perbankan di indonesia yang terdaftar di bursa efek indonesia mulai tahun 2005 sampai 2008 menunjukkan bahwa scara parsial ROE, EPS dan PER memiliki pengaruh yang signifikan terhadap harga saham sedangkan ROA dan IOS tidak memiliki pengaruh yang signifikan terhdap harga saham. Namun pengujian secara simultan menunjukkan ROA, ROE, EPS, PER, dan IOS memiliki pengaruh terhadap harga saham.

Menurut penelitian Hutami (2012) yang melakukan pengujian terhadap perusahaan industri manufaktur yang tercatat di bursa efek indonesia periode 2006 sampai 2010 menunjukkan bahwa secara simultan dan persial DPS, ROE, NPM memiliki pengaruh yang positif dan signifikan terhadap harga saham.

Menurut penelitian Watung dan Ilat (2016) yang melakukan pengujian terhadap perusahaan perbankan di bursa efek indonesia selama periode 2011 sampai 2015 menunjukkan bahwa secara simultan dan parsial, ROA, NPM dan EPS memiliki pengaruh yang signifikan terhadap harga saham.

Menurut penelitian Husaini (2012) yang melakukan pengujian pada perusahaan food and beverages yang terdaftar di bursa efek indonesia periode tahun 2006 sampai 2009 menunjukkan secara parsial hanya ROA, ROE saja yang memiliki pengaruh terhadap harga saham sedangkan NPM dan EPS tidak memiliki pengaruh terhadap harga saham. Secara simultan ROA, ROE, NPM dan EPS memiliki pengaruh terhadap harga saham.

Menurut penelitian Putra, Saryadi dan Hidayat (2013) yang melakukan pengujian pada perusahaan BUMN yang tercatat pada bursa efek indonesia pada tahun 2010 hingga 2012 menunjukkan bahwa ROE dan TATO berpengaruh positif dan signifikan namun CR dan ROI tidak memiliki pengaruh terhadap harga saham.

Menurut penelitian Azhari, Rahayu dan Zahroh (2016) yang melakukan pengujian pada perusahaanperusahaan real estate yang go public di bursa efek indonesia periode tahun 2007 sampai 2010 menunjukkan bahwa secara simultan ROE, DER, TATO dan PER memiliki pengaruh terhadap harga saham, sedangkan secara parsial hanya ROE dan PER saja yang memiliki pengaruh terhadap harga saham. Untuk DER dan TATO tidak memiliki pengaruh terhadap harga saham.

Diharapkan dengan Penelitian ini dapat memberikan manfaat bagi pengembangan ilmu pengetahuan, agar dapat memberikan kontribusi pada pengembangan teori dan dapat dijadikan sebagai bahan referensi yang berguna untuk penelitian berikutnya, khususnya yang berkaitan dengan pengaruh ROA, ROE, NPM, DER, CashTA, TATO dan EPS terhadap harga saham.

Manfaat secara operasional dari penelitian ini adalah agar dapat memberikan gambaran kepada manajemen perusahaan mengenai elemen-elemen yang sebaiknya digunakan oleh pihak investor sebagai dasar pengambilan keputusan sebuah perusahaan sebelum berinvestasi pada sebuah pasar saham, dan kepada investor dalam proses pengambilan keputusan untuk melakukan suatu investasi.

Hipotesis penelitian yang diharapkan adalah

- Apakah ROA (Return On Assets) berpengaruh signifikan terhadap harga saham, 
- Apakah ROE (Return On Equity) berpengaruh signifikan terhadap harga saham,

- Apakah NPM (Net Profit Margin) berpengaruh signifikan terhadap harga, apakah DER (Debt to Equity Ratio) berpengaruh signifikan terhadap harga saham,

- Apakah CashTA (Cash to Total Assets) berpengaruh signifikan terhadap harga saham,

- Apakah TATO (Total Assets Turnover) berpengaruh signifikan terhadap harga saham,

- Apakah EPS (Earning per Share) berpengaruh signifikan terhadap harga saham dan

- Apakah Return on Assets (ROA), Return on Equity (ROE), Net Profit Margin (NPM), Debt to Equity Ratio (DER), Cash to Total Assets (CashTA), Total Assets Turn Over (TATO), Earning Per Share (EPS) secara simultan berpengaruh signifikan terhadap harga saham.

Berdasarkan uraian di atas maka penelitian ini dilakukan untuk menguji pengaruh faktor fundamental terhadap harga saham dengan variable ROA, ROE, NPM, DER, CashTA, TATO dan EPS sebagai variable bebas dalam penelitian ini.

\section{Metode Penelitian}

Subjek penelitian ini adalah 65 perusahaan dalam industri manufaktur yang terdaftar di bursa efek Indonesia selama periode $2012-2015$.

Objek penelitian ini adalah ROA, ROE, NPM, DER, CTA, TATO, EPS, dan harga saham perusahaan dari tahun 2012 sampai dengan 2015.

Populasi dan sample yang digunakan dalam penelitian ini adalah perusahaan-perusahaan manufaktur yang sahamnya terdaftar di Bursa Efek Indonesia (BEI) selama periode 2012-2015. Metode yang digunakan untuk pemilihan sampel dalam penelitian ini yaitu metode purposive sampling. Pemilihan sampel dengan metode ini dipilih secara tidak acak, yaitu dengan kriteria kriteria tertentu antara lain:

Seluruh perusahaan manufaktur yang terdaftar di Bursa Efek tahun 2012-2015 sebanyak 192 perusahaan (Data perusahaan manufaktur pada tahun 2012).

Perusahaan yang memiliki data harga saham serta memiliki volume transaksi dari hari pertama Hingga kelima sebelum tanggal penerbitan laporan keuangan dan hari pertama sampai hari kelima setelah tanggal penerbitan laporan keuangan.

Operasionalisasi variable untuk variabel yang digunakan dalam penelitian ini adalah variable bebas (independent variable) dan variable terikat (dependent variable). Return on Assets (ROA), Return On Equity (ROE), Net Profit Margin (NPM), Debt to equity Ratio (DER), Cash to Total Asset (CashTA), Total Asset Turnover (TATO) dan Earning per Share (EPS) digunakan sebagai variable bebas. Untuk variable terikatnya adalah harga saham.

Teknik analisis data yang digunakan adalah analisis regresi data panel yang mengkombinasikan hubungan variabel bebas terhadap variabel terikat cross-section dan time series.

\section{Data Panel}

Berikut hasil uji statistik deskriptif dari pengujian. 
Tabel 1. statistik deskriptif

\begin{tabular}{|c|c|c|c|c|c|c|c|c|}
\hline & ROA? & ROE? & NPM? & DER? & CTA? & TATO? & EPS? & HS? \\
\hline Mean & 8.817000 & 14.06019 & 7.782000 & 0.972115 & 0.224908 & 1.175182 & 755.8958 & 10642.82 \\
\hline Median & 6.885000 & 12.49500 & 6.025000 & 0.720000 & 0.058285 & 1.100518 & 93.98000 & 1120.000 \\
\hline Maximum & 74.84000 & 76.43000 & 50.87000 & 7.400000 & 26.79345 & 3.654583 & 17621.38 & 360000.0 \\
\hline Minimum & 0.040000 & 0.060000 & 0.120000 & 0.080000 & 0.001908 & 0.221916 & 0.020000 & 50.00000 \\
\hline Std Dev. & 8.544070 & 11.36193 & 7.035190 & 0.967896 & 1.662565 & 0.551331 & 2193_842 & 40029.69 \\
\hline Skewness & 2.713132 & 2.085628 & 1.928210 & 3.018602 & 15.78945 & 1.097751 & 5.185759 & 6.639846 \\
\hline Kurtosis & 17.02130 & 11.22705 & 9.048789 & 15.01241 & 252.7750 & 4.995234 & 33.17157 & 51.61463 \\
\hline Jarque & & & 14 & 79 & 686 & & & \\
\hline Probability & 0.000000 & 0.000000 & 0.000000 & 0.000000 & 0.000000 & 0.000000 & 0.000000 & 0.000000 \\
\hline & & & & & & & & \\
\hline Sum & 2292.420 & 3655.650 & 2023.320 & 252.7500 & 58.47612 & 305.5472 & 196532.9 & 2767133 \\
\hline $\begin{array}{l}\text { Sum Sq. } \\
\text { Dev. }\end{array}$ & 1890729 & 3343523 & 12818.92 & 242.6369 & 715.9078 & 78.72720 & 1. $25 E+09$ & 4. $15 E+11$ \\
\hline Observations & 260 & 260 & 260 & 260 & 260 & 260 & 260 & 260 \\
\hline $\begin{array}{l}\text { Cross } \\
\text { sections }\end{array}$ & 65 & 65 & 65 & 65 & 65 & 65 & 65 & 65 \\
\hline
\end{tabular}

Statistic Descriptive

Berikut adalah hasil regresi data panel dengan menggunakan random effect model.

Tabel 2. hasil regresi data panel dengan menggunakan random effect model.

\begin{tabular}{|c|c|c|c|c|}
\hline Variable & Coefficient & Std. Error & t-Statistic & Prob. \\
\hline $\begin{array}{c}\text { O } \\
\text { ROA? } \\
\text { ROE? } \\
\text { NPM? } \\
\text { DER? } \\
\text { OTA? } \\
\text { TATO? } \\
\text { EPS? } \\
\text { Random Effects (Cross) }\end{array}$ & $\begin{array}{r}523.5384 \\
839.6916 \\
251.5076 \\
-993.2757 \\
162.2386 \\
-2362.470 \\
-3481.917 \\
15.04791\end{array}$ & $\begin{array}{l}5369.193 \\
466.5941 \\
242.1201 \\
481.1038 \\
1761.713 \\
825.3209 \\
3888.329 \\
0.823479\end{array}$ & $\begin{array}{r}0.097508 \\
1.799619 \\
1.038772 \\
-2.064577 \\
0.092091 \\
-2.862486 \\
-0.895479 \\
18.27358\end{array}$ & $\begin{array}{l}0.9224 \\
0.0731 \\
0.2999 \\
0.0400 \\
0.9267 \\
0.0046 \\
0.3714 \\
0.0000\end{array}$ \\
\hline \multicolumn{5}{|c|}{ Effects Specification } \\
\hline $\begin{array}{l}\text { Cross-section random } \\
\text { ldiosyncratic random }\end{array}$ & & & $\begin{array}{l}8468.658 \\
20164.33\end{array}$ & $\begin{array}{l}0.1499 \\
0.8501\end{array}$ \\
\hline \multicolumn{5}{|c|}{ Weighted Statistics } \\
\hline $\begin{array}{l}\text { R-squared } \\
\text { Adjusted R-squared } \\
\text { S-E. of regression } \\
\text { F-statistic } \\
\text { Prob(F-statistic) }\end{array}$ & $\begin{array}{l}0.639440 \\
0.629425 \\
20242.57 \\
63.84480 \\
0.000000\end{array}$ & $\begin{array}{l}\text { Mean dependent var } \\
\text { S.D. dependent var } \\
\text { Sum squared resid } \\
\text { Durbin-Wvatson stat }\end{array}$ & & $\begin{array}{l}8149.402 \\
33252.75 \\
1.03 E+11 \\
1.440749\end{array}$ \\
\hline \multicolumn{5}{|c|}{ Unweighted Statistics } \\
\hline $\begin{array}{l}\text { R-squared } \\
\text { Sum squared resid }\end{array}$ & $\begin{array}{l}0.710155 \\
1.20 E \div 11\end{array}$ & $\begin{array}{l}\text { Mean dependent var } \\
\text { Durbin-Vyatson stat }\end{array}$ & & $\begin{array}{l}10642.82 \\
1.236773\end{array}$ \\
\hline
\end{tabular}

Output regresi data panel dengan random effect model

Persamaan regresi linier berganda hasil penelitian adalah sebagai berikut:

$\mathrm{Y}=523,5384+839,6916 \mathrm{ROA}+251,5076 \mathrm{ROE}-993,2757 \mathrm{NPM}+162,2386 \mathrm{DER}-2362,470 \mathrm{CTA}-$ $3481,917 \mathrm{TATO}+15,04791 \mathrm{EPS}$

ROA, ROE, DER, TATO, tidak signifikan mempengaruhi harga saham perusahaan manufaktur yang terdaftar di bursa efek Indonesia dari tahun 2012 sampai dengan 2015 dengan tingkat keyakinan 95\%.

NPM, CashTA, EPS signifikan positif mempengaruhi harga saham perusahaan manufaktur yang terdaftar di bursa efek Indonesia dari tahun 2012 sampai dengan 2015 dengan tingkat keyakinan 95\%.

Koefisien determinasi (Uji R2) nilai koefisien determinasi adalah 0,629425. Ini berarti bahwa variasi harga saham dapat dijelaskan oleh variasi variabel Return On Asset, Return On Equity, Net Profit Margin, Debt to 
Equity Ratio, Cash to Total Assets, Total Asset Turnover dan Earning per Share sebesar 62,9425\%. Sisanya sebesar 37,0575\% dijelaskan oleh variabel lain.

\section{Diskusi}

ROA tidak signifikan mempengaruhi harga saham. Ini sejalan dengan penelitian terdahulu yang pernah dilakukan oleh Nainggolan (2008), Raharjo (2013), dan Tampubolon (2011). Namun penelitian ini tidak sejalan dengan penelitian terdahulu yang pernah dilakukan oleh Pandansari (2012), Jiwandono (2014), Watung (2016) dan Husaini (2012). Peningkatan rasio ROA bisa mengindikasikan bahwa penggunaan aktiva semakin berkurang dapat berpengaruh terhadap operasional yang dilakukan oleh perusahaan sehari hari dalam melakukan penjualan sehingga perolehan laba akan menyusut dan dapat diasumsikan bahwa kinerja perusahaan menurun.

ROE tidak signifikan mempengaruhi harga saham. Ini sejalan dengan penelitian terdahulu yang pernah dilakukan oleh Nainggolan (2008), Jiwandono (2014), Gunarianto (2012), Raharjo (2013) dan Husaini (2012). Namun penelitian ini tidak sejalan dengan penelitian terdahulu yang pernah dilakukan oleh Deitiana (2011), Tampubolon (2011), Hutami (2012), Putra (2013) dan Azhari (2016). Seharusnya berdasarkan teori signal, semakin tingginya nilai ROE akan mendorong para invetor untuk bahwa perusahaan mampu menghasilkan profitabilitas yang baik. Namun dalam pengujian yang dilakukan ROE tidak memiliki pengaruh yang signifikan terhadap harga saham. Dalam penelitian ini berarti signaling theory tidak berjalan sewajarnya hal ini dapat terjadi karena faktor faktor yang mungkin masih belum dimasukkan ke dalam penelitian ini.

NPM signifikan negatif mempengaruhi harga saham. Ini sejalan dengan penelitian terdahulu yang pernah dilakukan oleh Hutami (2012) dan Watung (2016) Namun penelitian ini tidak sejalan dengan penelitian terdahulu yang pernah dilakukan oleh Husaini (2012). Variabel ini memiliki efek yang signifikan terhadap harga saham namun efek yang diberikan adalah negatif. Hal ini tidak sejalan dengan hipotesis yang telah saya buat sebelumnya di mana seharusnya NPM ini berpengaruh signifikan dan positif. Ini mungkin terjadi akibat investor yang sudah mulai meninggalkan model penilaian dengan hanya memperhatikan profitabilitas suatu perusahaan.

DER tidak signifikan mempengaruhi harga saham. Ini sejalan dengan penelitian terdahulu yang pernah dilakukan oleh Raharjo (2013) dan Azhari (2016). Namun penelitian ini tidak sejalan dengan penelitian terdahulu yang pernah dilakukan oleh Pandansari (2012). Rasio DER semakin tinggi menunjukkan perusahaan lebih banyak menggunakan hutang untuk kegiatan operasionalnya. Semakin tingginya rasio ini maka menandakan bahwa tingkat leverage yang tinggi yang berarti akan mengurangi dividen yang diperoleh investor. Hal ini disebabkan oleh perusahaan yang emmiliki leverage yang tinggi maka harus menggunakan pendapatan mereka untuk melunasi kewajiban kewajibannya.

CashTA signifikan negatif mempengaruhi harga saham. Ini sejalan dengan penelitian terdahulu yang pernah dilakukan oleh Pasaribu (2008). Namun penelitian ini tidak sejalan dengan penelitian terdahulu yang pernah dilakukan oleh Anjas (2015). CashTA merupakan salah satu instrumen yang menggambarkan likuiditas perusahaan namun dalam pengujian ini menunjukkan bahwa rasio likuiditas ini malah menghasilkan penurunan nilai saham apabila terjadi peningkatan poin. Seharusnya apabila kita melihat dari segi signaling theory seharusnya cashTA memiliki pengaruh yang positif. Ini menunjukkan bahwa mungkin banyak investor yang tidak melihat likuiditas ini berpengaruh baik terhadap peningkatan kinerja perusahaan sehingga peningkatan nilai pada rasio cashTA berakibat pada penurunan harga saham.

TATO tidak signifikan mempengaruhi harga saham. Ini sejalan dengan penelitian terdahulu yang pernah dilakukan oleh Azhari (2016). Namun penelitian ini tidak sejalan dengan penelitian terdahulu yang pernah dilakukan oleh Putra (2013). Hasil penelitian ini menunjukkan bahwa perputaran total aktiva yang diukur dari penjualan, artinya kemampuan semua aktiva dalam menciptakan penjualan belum tentu dapat meningkatkan laba. Ketidakmampuan perusahaan dalam meningkatkan laba ini mungkin diakibatkan karena pembayaran hutang sehingga mengurangi laba perusahaan.

EPS signifikan positif mempengaruhi harga saham. Ini sejalan dengan penelitian terdahulu yang pernah dilakukan oleh Seetharaman (2011). Namun penelitian ini tidak sejalan dengan penelitian terdahulu yang pernah dilakukan oleh Gunarianto (2012). Hal ini menggambarkan bahwa perusahaan mampu untuk 
mendistribusikan pendapatan kepada pemegang sahamnya, hal ini menunjukkan bahwa investor lebih percaya terhadap nilai pengembalian oleh perusahaan karena EPS menunjukkan tingkap pengembalian yang diperoleh investor apabila melakukan pembelian saham.

\section{Penutup}

Secara garis besar dapat disimpulkan bahwa rasio profitabilitas signifikansinya hanya dari variable NPM dan efek signifikannya adalah negatif sedangkan ROA dan ROE tidak memiliki pengaruh yang signifikan terhadap harga saham.

Untuk rasio likuiditas yang diwakili oleh CashTA memiliki efek signifikan namun negatif dan untuk rasio solvabilitas yang diwakili oleh DER ternyata tidak memiliki pengaruh yang signifikan juga. Sedangkan EPS memiliki efek yang signifikan dan positif.

Dari hasil penelitian ini kita dapat melihat bahwa Profitabilitas tidak menjadi salah satu tolak ukur yang menentukan dalam pengambilan keputusan pembelian saham.

Berdasarkan hasil kesimpulan yang didapat penulis dalam penelitian ini maka penulis memberikan saran:

- Variabel NPM, CTA, dan EPS adalah variabel yang layak digunakan untuk memprediksi besarnya harga saham. Hal ini dapat dijadikan panduan bagi para manajer keuangan untuk memprediksi besarnya harga saham. Namun perlu diingat bahwa NPM dan CTA memiliki pengaruh yang negative terhadap harga saham dan hanya EPS saja yang berpengaruh positif terhadap harga saham.

- Untuk penelitian selanjutnya penggunaan sampel dalam industri lain dan penggunaan sampel pada periode tahun yang berbeda dapat memberikan gambaran yang lebih luas dan dapat meningkatkan keakuratan hasil penelitian.

- Sebaiknya menggunakan data time series yang lebih banyak untuk meneliti pengaruh yang lebih luas lagi.

\section{Daftar Rujukan / Pustaka}

Alexandri, Moh. Benny. (2008). Manajemen Keuangan Bisnis. Cetakan Kesatu. Bandung: Alfabeta.

Anjas Kusumadewi. (2015). Pengaruh Likuiditas dan Profitabilitas terhadap Harga Saham Perusahaan Manufaktur yang Terdaftar di Bursa Efek Indonesia Periode 2010-2013. Jurnal Akuntansi Vol. 3, No. 2.

Agus R. Sartono. (2007) . Manajemen Keuangan : Teori dan Aplikasi , Jakarta: PT Raja Grafindo Persada.

Azhari, Diko Fitriansyah; Sri Mangesti Rahayu dan Zahroh Z.A.. (2016). Pengaruh ROE, DER, TATO dan PER Terhadap Harga Saham Perusahaan Properti dan Real Estate yang Go Public di Bursa Efek Indonesia. Jurnal Administrasi Bisnis (JAB), Vol.32, No.2, Maret 2016.

Baresa, Suzana ; Sinisa Bogdan and Zoran Ivanovic. (2013). Strategy of Stock Valuation by Fundamental Analysis. UTMS Journal of Economics, Vol.4, No.1, Hlm.45-51, Tahun 2013.

Baridwan,Zaki.2000. Intermediate Accounting. Yogjayakarta: BPFE.

Benartzi,S., R. Michaely and R. Thaler.1997. Do Change in Dividend Signal the Future or the Past?, The Journal of Finance, R(july): 1007-1033.

Besley, Scott and Brigham,Eugene F.(2000). Essential of Managerial Finance. $12^{\text {th }}$ Edition. Sea Harbor Drive, Orlando : Harcourt,Inc.

Bodie, Zvi, Alan J. Marcus and Alex Kane. (2004). Investments (Irwin Series in Finance). $6^{\text {th }}$ edition. McGraw-Hill/Irwin.

Brealey, Myers dan Marcus . 2007 . Dasar-Dasar Manajemen Keuangan Perusahaan. Jakarta : Erlangga.Edisi 5.

Brigham, Eugene F. dan Houston F. Joel. (2009). Dasar-dasar Manajemen Keuangan. Edisi 10. Jakarta: Salemba Empat.

Darmadji, tjiptono dan hendy, M. fakhruddin . (2011). Pasar Modal di Indonesia. Edisi 3. Salemba Empat.

Deitiana, Tita. (2011). Pengaruh Rasio Keuangan, Pertumbuhan Penjualan dan Dividen Terhadap Harga Saham. Jurnal Bisnis dan Akuntansi, Vol.13, No.1, Hlm.57-66, April 2011.

Elis Darnita. (2013). Analisis Pengaruh Return On Assets (ROA), Return On Equity (ROE), Net Profit Margin (NPM) Dan Earning Per Share (EPS) Terhadap Harga Saham (Studi Pada Perusahaan Food 
Dan Beverages Yang Terdaftar Di Bursa Efek Indonesia (BEI) Pada Tahun 2008-2012). Jurnal Keuangan, Vol. 2, No. 1.

Gitman, L.J 2003 Principle Of Managerial Finance.Tenth Edition . Boston: Adisson Wesley.

Gujarati, Damodar. (2004). Basic Econometrics, 4th Edition. McGraw-Hill/Irwin.

Gunarianto. (2012). Analisis Earning per Share dan Return on Equity Serta Tingkat Bunga Deposito Terhadap Harga Saham Perbankan di Bursa Efek Indonesia. Jurnal Manajemen dan Akuntansi, Vol.1, No.2, Agustus 2012.

Harahap,Sofyan Syafri.2007. Analisis Kritis dan Laporan Keuangan.Jakarta: PT Raja Grasindo Persada.

Horne, James C. Dan Wachowics, John M. Jr. ( 1998 ). Fundamentals of financial management. Edisi kesepuluh. USA: Prentice-Hall International, Inc.

Husaini, Achmad. (2012). Pengaruh Variabel Return on Assets, Return on Equity, Net Profit Margin dan Earning per Share Terhadap Harga Saham Perusahaan. Jurnal Profit, Vol.6, No.1, Juni 2012.

Hutami, Rescyana P. (2012). Pengaruh Dividend Per Share, Return on Equity dan Net Profit Margin Terhadap Harga Saham Perusahaan Industri Manufaktur yang Tercatat di Bursa Efek Indonesia Periode 2006-2010. Jurnal Nominal, Vol.1, No.1, Tahun 2012.

I Gusti Ayu Purnamawati. (2016). The Effect Of Capital Structure And Profitability On Stock Price (Study Of The Manufacturing Sector In Indonesia Stock Exchange). International Journal of Business, Economics and Law, Vol. 9, No. 1.

Ikatan Akuntansi Indonesia. 2009. Standar Akuntansi Keuangan.Jakarta: Salemba Empat.

Ririn V dan Iin I. (2010). Pengaruh Stabilitas Penjualan, Struktur Aktiva DanTingkat Pertumbuhan Terhadap Struktur Modal (Studi Empiris Terhadap Perusahaan Real Estate and Property yang Terdaftar di BEI Tahun 2007-2009). Jurnal Akuntansi Keuangan, Vol. 3, No. 2.

Jiwandono, Teguh. (2014). Analisis Faktor Fundamental Terhadap Harga Saham Sektor Perbankan yang Go Public di Indeks Kompas 100. Jurnal Ilmu Manajemen 1, Vol.2, No.3, Juli 2014.

Jogiyanto Hartono, 2013. Teori Portofolio dan Analisis Investasi, BPFE Yogyakarta, Edisi Kedelapan Yogyakarta.

Jones, Charles P. (2002). Investments Analysis and Management. 8th edition. New York: John Wiley \& Sons, Inc.

Kartašova, Jekaterina and Deimant Venclauskien. (2014). Valuation of Fundamental Analysis Reliability in Stock Pricing : Theoritical Approach. 8th International Scientific conference Business and Management, 2014 May 15-16, Vilnius, LITHUANIA Section: Finance Engineering, 2014.

Kieso,Weygandt,dan Warfield. 2011. Intermediate Accounting Vol.1. United States of America:John

Wiley \& Sons,Inc.IFRS Edition.

Mardiyanto, Handoyo.2009. Intisari Manajemen Keuangan.Jakarta : PT Grasindo.

Mpra.ub.uni-muenchen.de/36979/

Myers, S. C. and Marcus, A. J. (2004). Principles of Corporate Finance, Seventh Edition. New York: McGraw-Hill Inc.

Nainggolan, Susan Grace Veranita. (2008). Pengaruh Variabel Fundamental Terhadap Harga Saham Perusahaan Manufaktur yang Terdaftar di BEI. USU e-repository. Tahun 2008.

Pandansari, Arum Fillya. (2012). Analisis Faktor Fundamental Terhadap Harga Saham. Accounting Analysis Journal, Vol.1, Tahun 2012.

Pasaribu, Rowland B. F. (2008). Pengaruh Variabel Fundamental Terhadap Harga Saham Perusahaan Go Public di Bursa Efek Indonesia (BEI) Periode 2003-2006. Jurnal Ekonomi dan Bisnis, Vol.2, No.2, Juli 2008.

Putra, Aldiansyah Cahya; Saryadi dan Wahyu Hidayat. (2013). Pengaruh Kinerja Keuangan Terhadap Harga Saham pada Perusahaan BUMN (Non-Bank) yang Terdaftar di Bursa Efek Indonesia. Diponegoro Journal of Social and Politic, Hal.1-9, Tahun 2013.

Raharjo, Daniarto dan Dul Muid. (2013). Analisis Pengaruh Faktor-Faktor Fundamental Rasio Keuangan Terhadap Perubahan Harga Saham. Diponegoro Journal of Accounting, Vol.2, No.2, Hlm.1-11, Tahun 2013.

Riyanto, Bambang. (2008). Dasar-dasar Pembelajaran Perusahaan. Edisi 1. Yogyakarta: BPFE. 
Seetharaman, A. and John Rudolph Raj. (2011). An Empirical Study on Impact of Earnings per Share on Stock Prices of a Listed Bank in Malaysia. Journal International of Applied Economics and Finance 5 (2) : 114-126, 2011.

Siamat, Dahlan. (2005). Manajemen Lembaga Keuangan Kebijakan Moneter dan Perbankan Edisi Kelima. Jakarta: LP FE Universitas Indonesia.

Soemarsono.2004. Akuntansi Suatu Pengantar.Jakarta : Salemba Empat.Buku 1.Edisi 5.

Tampubolon, Bantu dan Ardin Doloksaribu. (2011).Pengaruh Faktor Fundamental dan Investment Oppurtunity Set (IOS) Terhadap Harga Saham Emiten Manufaktur di Bursa Efek Indonesia. Lembaga Penelitian Universitas HKBP Nommensen Medan. Tahun 2011.

Tandelilin, Eduardus. (2010). Portofolio dan investasi: Teori dan aplikasi. Edisi 1. Jakarta: Kanisius.

Ross, Stephen A.; Randolph W. Westerfield ; Jeffrey Jaffe,dan Bradford D. Jordan. (2009). Modern financial management. Edisi kedelapan. Singapore: Mc Graw-Hill Education.

Siegel dan Shim. (1999). Kamus istilah akuntansi : alih bahasa oleh Moh.Kurdi. Edisi 1. Jakarta: Gramedia.

Warren, Carl S.; Reeve, James M. and Fess, Phillip E.2005. Accounting. $21^{\text {th }}$ Edition. Cincinati, Ohio: South - Western College Publishing.

Watung, Rosdian Widiawati dan Ventje Ilat. (2016). Pengaruh Return on Asset (ROA), Net Profit Margin (NPM), dan Earning per Share (EPS) Terhadap Harga Saham Pada Perusahaan Perbankan di Bursa Efek Indonesia Periode 2011-2015. Jurnal EMBA, Vol.4, No.2, Hal.518-529, Juni 2016.

Widarjono, Agus. (2010). Analisis Statistika Multivariat Terapan. Yogyakarta: UPP STIM YKPN.

Wild, John,K.R Subramanyam,dan Robert F.Halsey. (2009). Financial StatementAnalysis,9thed. Singapore: McGraw-Hill.

Widoatmojo, Sawidji. (2008). Cara Sehat Investasi di Pasar Modal: Pengantar menjadi Investor Profesional. Jakarta: Elex Media Komputindo. 